[ J.Soc. Cosmet. Chem. Jpn.

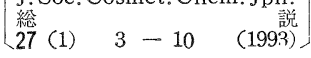

\title{
顔料の触媒活性と表面修飾
}

\author{
福井 寛 \\ 株式会社 資生堂基礎科学研究所 $\uparrow$
}

\section{Catalytic Activity and Surface Modification of Pigments}

\author{
Hiroshi Fukui \\ Shiseido Basic Research Laboratories. $†$
}

(1) Catalytic activity of pigments often causes problems in mixture systems used in cosmetics, such as oxidation of oils and decomposition of perfumes. These pigments generally contain transition elements, such as chromium, iron, and manganese. Linalool, a common component of perfumes, is dehydrated via a carbonium-ion intermediate at acidic sites of the pigments. Linalool molecules experience allyl rearrangement to form a cyclized structure. The cyclized molecules are further dehydrogenated to result in $p$-cymene, which is a main cause of unpleasant odor in certain pigmented cosmetics.

(2) Surfaces of the pigments used in cosmetics were modified with various chemical substances, which include metal oxides, metallic soap, silicone-and fluorine-contained compounds. In particular, a novel two-step method to produce pigments possessing various functional groups was developed. The method consists of chemical vapor deposition of 1,3,5,7-tetramethylcyclotetrasiloxane and hydrosilylation of various vinyl compounds. The silicone film formed on the pigments at the first step has a thickness of less than $1.0 \mathrm{~nm}$ and various functional groups could be attached to the film.

\section{1. はじめに}

仕上げ用化粧品は化粧品出荷の約 $25 \%$ を占めて いる。この仕上げ用化粧品にはファンデーショ ン, 抗しろい, 口紅, 汪汪紅, アイメークアップ, まゆ墨まつ毛用化粧料，つめ化粧料などがある が，これらには必ず顔料が配合されている。

ファンデーションや执しろいには隠蔽力のない 体質顔料 (タルク, 雲母), 白色顔料 (二酸化チタ ン，亜鉛華）和よび有色顔料（酸化鉄など）が用 いられている。この様な顔料は単独で用いられる

$\dagger$ 于223 横浜市港北区新羽町 $1050 ； 1050 \mathrm{Nippa}-$ cho, Kohoku-ku Yokohama 223 Japan
ことはなく, 通常は油脂, 香料, 界面活性剤, 薬 剤などと混合したり，さらに水が配合された乳化 系に分散して製品とする。したがって触媒活性の 強い顔料は化粧品の系では不均一触媒として働 き，化粧品の変質拉よび変臭の原因となる。 化粧品に扮ける顔料の触媒作用の研究は一般的 には余り行われていないが，化粧品の処方を組む 上で重要である。そこで本稿では化粧品に含まれ る他成分, 特に油脂の酸化と香料の分解に特よぼ す顔料の触媒作用について述べる。

また，近年化粧品分野に扮いて様々な表面修飾 が報告されており，本稿では，特許などに見られ る表面修飾の紹介と筆者らが開発した反応型超薄 膜コーティングについて述べる。 


\section{2. 顔料の触媒作用による化粧品成分の劣化}

\section{1 油脂の酸化}

油脂の酸化安定性は一般に AOM (Active Oxygen Method) によって行われ, 経時での過 酸化物価, 酸価, カルボニル価などで評価されて いる。しかしながら顔料が添加された油脂系では 顔料と油脂の分離が事実上不可能であり, 過酸化 物価などの滴定ができない。

一方, 熱測定は酸化による発熱を直接測定でき ることから，指示薬を用いた滴定の必要がなく， 顔料などが添加されている系での酸化の評価に適 している。

Cross は示差走査熱量計 (DSC) 用いて酸素 気流中で油脂の酸化熱を測定することによって種 々の油脂の酸化安定性を評価した1)。筆者らはこ の方法を用いて顔料のヒマシ油酸化能を検討し た2)。

図ー1 はヒマシ油に顔料を添加した試料 $20 \mathrm{mg}$ を酸素気流中 $(10 \mathrm{~mL} / \mathrm{min})$ 飞設置し, 昇温して 一定温度に保ち TG-DTAを測定した結果であ る。

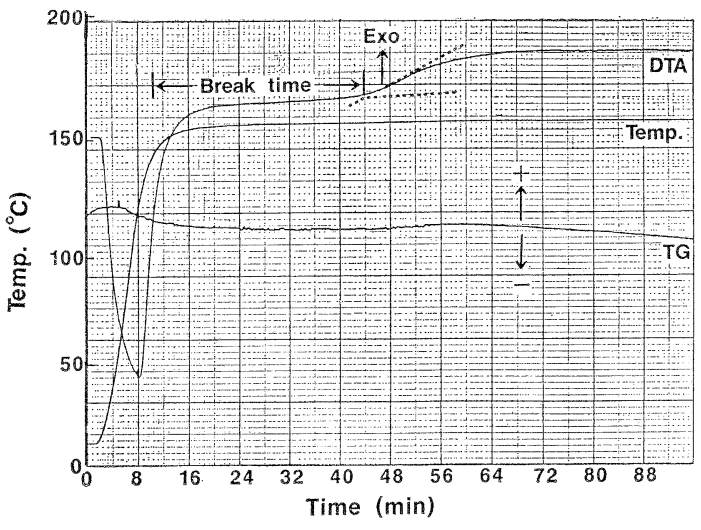

図一－15\%の赤色酸化鉄を含むヒマシ油の $157^{\circ} \mathrm{C}$ に特けるTG和よび DTA 曲線

Sample size : $20 \mathrm{mg}$

$$
\mathrm{O}_{2}: 10 \mathrm{~m} 1 / \mathrm{min}
$$

一定時間後に発熱ピークがあらわれるが，これ は窒素気流中ではあらわれないことからヒマシ油 の酸化による発熱と考光られる。一定温度になっ てから発熱ピークが出現するまでの時間をbreak time とし, 同一ヒマシ油で AOM による過酸化 物価が 100を越觉る時間 (AOM day) との関係を 検討した結果, ヒマシ油の break time と AOM day には良い相関関係があった。

このことから, 油脂の酸化評価に酸素ガスフロ 一 DTA 法が適用できることがわかる。各種顔料 を20\%添加したヒマシ油の $170^{\circ} \mathrm{C}$ に打訬る break timeを表一1によとめた。

表一1 各種顔料を20\%添加したヒマシ油の $170^{\circ} \mathrm{C}$ に和ける break time

\begin{tabular}{l|r|c}
\hline \multicolumn{1}{c|}{ Pigments } & $\begin{array}{r}\text { S.S.A. } \\
\left(\mathrm{m}^{2} / \mathrm{g}\right)\end{array}$ & $\begin{array}{c}\text { Break time of } \\
\text { castor oil (min) }\end{array}$ \\
\hline Hydrated chromium & 80.0 & 0.1 \\
oxide & 15.4 & 1.8 \\
Red iron oxide & 19.9 & 2.1 \\
Yellow iron oxide & 5.7 & 2.3 \\
Black iron oxide & 30.3 & 2.4 \\
Prussian Blue & - & 5.8 \\
Manganese violed & 4.0 & 17.6 \\
Zinc oxide & - & 26.6 \\
(None) & 11.8 & 27.9 \\
Kaolinite & 7.7 & 29.7 \\
Mica & 9.1 & 33.0 \\
Ultramarine & 200.2 & 40.0 \\
Silica & 11.3 & 54.0 \\
Talc & 55.8 & 132.3 \\
Titanium dioxide A & 14.9 & 158.5 \\
Titanium dioxide B & & \\
\hline
\end{tabular}

Break time を短くする顔料は含水酸化クロム や酸化鉄など遷移元素を含もものであった。特に 鉄を含む顔料は break time が 1.8～2.4 分と非 常に似た值を示し，ヒマシ油の酸化には $\mathrm{Cr}>\mathrm{Fe}$ $>\mathrm{Mn}$ の順で酸化促進効果が認められた。これら の結果は鉄やクロムの添加が油脂の酸化を促進す

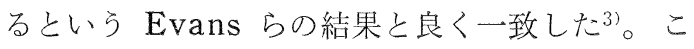
のように顔料を含も油脂の評価は酸素ガスフロー DTA 法で簡便に測定できる。

この方法は

(1) 試料が少なくても測定でさる (10mg 程度)

(2) 迅速に測定できる

(3) Arrenius 型のプロットが可能であり低温 
での推定ができる

といった特長を持っており，一次スクリーニン グに適している。

\section{2 香料の分解}

Holznerはタルクやカオリンと香料成分のリナ ロールやリナリルアセテートを共存させて拈く 之，時間とともに香料成分が減少していくことを 報告している( ${ }^{4)}$ が，一般に顔料による香料成分の 変化についての報告は少ない。

筆者らは香料成分が顔料の触媒作用によって分 解すると仮定して，パルス反応装置を用いてアル コールの脱水・脱水素反応から固体酸・塩基を評 価した。パルス反応装置はガスクロマトグラフの 前に顔料を充填した反応炉を接続したものである 。香料成分が触媒活性のある顔料層を通過すると その層で分解し，その分解物はガスクロマトグラ フに導入され分析される。

この方法は,

(1) 試料が少量でよい

(2) 測定が迅速である
(3) 反応温度が簡単に設定できる

(4) 反応の解析ができる

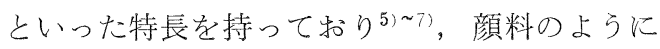
色のついた粉末でも測定できる。この装置を用い て香料成分の分解を検討した結果を紹介する。

表一 2 に各種顔料のリナロール分解率扣よび分 解生成物分布を示す 8 。

西鉛華では分解生成物は認められず, 分解率の 低い黑色酸化鉄や含水酸化クロムでは I， II， III が生成するのみである。顔料の分解活性が高くな るにつれて順次, IV, V, VI 新しい化合物が生 成し，最終的にはIXが生成する。これらの分解物 IからIXを大量に捕集し，ガスクロマトグラフ質 量分析計 (GC/MS) とガスクロマトグラフ赤外分 光計 $(\mathrm{GC} / \mathrm{IR})$ で分離同定し, 推定したリナロー ルの分解機構を図ー2 に示した。

リナロールが固体酸によって脱水し，その後異 性化していくことがわかる。

調否師による匂いの判定では，アロオシメン， テルビノレン， $\alpha$-テルピネンはカンフアーライク

表 -2 各種顔料によるリナロールの分解

\begin{tabular}{|c|c|c|c|c|c|c|c|c|c|c|c|}
\hline \multirow{2}{*}{ Pigments } & \multirow{2}{*}{$\begin{array}{l}\text { Linalool } \\
\text { recovery } \\
(\%)\end{array}$} & \multicolumn{10}{|c|}{ Product distribution (\%) } \\
\hline & & I & II & III & $\mathbb{N}$ & V & V & VII & VIII & $\mathbb{X}$ & Other \\
\hline Zinc oxide & 86.5 & nd & nd & nd & nd & nd & nd & nd & nd & nd & nd \\
\hline Black iron oxide & 57.5 & 75.0 & 12.5 & 12.5 & nd & nd & nd & nd & nd & nd & nd \\
\hline Hydrated chromium oxide & 54.0 & 73.3 & nd & 26.7 & nd & nd & nd & nd & nd & nd & nd \\
\hline Cobalt blue & 34.5 & 64.3 & 11.9 & 16.7 & 7.1 & nd & $\operatorname{tr}$ & $\operatorname{tr}$ & nd & nd & nd \\
\hline Silica & 23.0 & 50.0 & 15.6 & 21.9 & 12.5 & $\operatorname{tr}$ & nd & nd & nd & nd & nd \\
\hline Mica & 34.5 & 43.6 & 12.0 & 25.6 & 10.5 & 2.3 & nd & nd & nd & nd & 6.10 \\
\hline Yellow iron oxide & 15.0 & 43.7 & 12.5 & 16.3 & 22.5 & 5.0 & nd & nd & nd & nd & nd \\
\hline Talc & 25.0 & 19.4 & 12.9 & 14.4 & 13.7 & 10.1 & 7.2 & 10.9 & 9.4 & $\operatorname{tr}$ & 2.0 \\
\hline Titanium dioxide $\mathrm{A}$ & 20.5 & 26.2 & 12.3 & 12.3 & 18.0 & 13.1 & 8.2 & 9.8 & nd & nd & 0.1 \\
\hline Ultramarine blue & 18.5 & 46.2 & 14.3 & 24.4 & 11.7 & 1.7 & 0.8 & 0.8 & nd & nd & 0.1 \\
\hline Titanium dioxide $R$ & 9.5 & 24.0 & 15.6 & 13.5 & 12.5 & 7.3 & 5.2 & 11.4 & 10.4 & nd & 0.1 \\
\hline Titanium dioxide $A-R$ & 7.5 & 20.9 & 6.8 & 10.5 & 12.6 & 7.9 & 4.2 & 7.3 & 5.8 & nd & 24.0 \\
\hline Ultramarine violet & 2.5 & 25.4 & 10.9 & 17.4 & 12.3 & 7.2 & 2.9 & 4.3 & 8.0 & 7.2 & 4.4 \\
\hline Prussian blue & 1.0 & 10.0 & 6.9 & 7.7 & 6.9 & 3.1 & 1.5 & 1.5 & 6.9 & 30.8 & 24.7 \\
\hline Kaolinite & 0.5 & 7.9 & 1.1 & 9.1 & 1.1 & 11.4 & 5.7 & 9.1 & 30.7 & 11.4 & 12.5 \\
\hline Red iron oxide & 1.0 & 11.3 & 7.2 & 12.4 & 13.4 & 12.9 & 4.6 & 6.2 & 16.5 & 8.8 & 6.7 \\
\hline
\end{tabular}

Reaction temp., $178^{\circ} \mathrm{C}$; carrier gas, $\mathrm{N}_{2} 50 \mathrm{~mL} / \mathrm{min}$; pigment amount, $10 \mathrm{mg}$; pulse size, $0.3 \mu \mathrm{L}$; nd, no detectable amount of decomposition product found. 


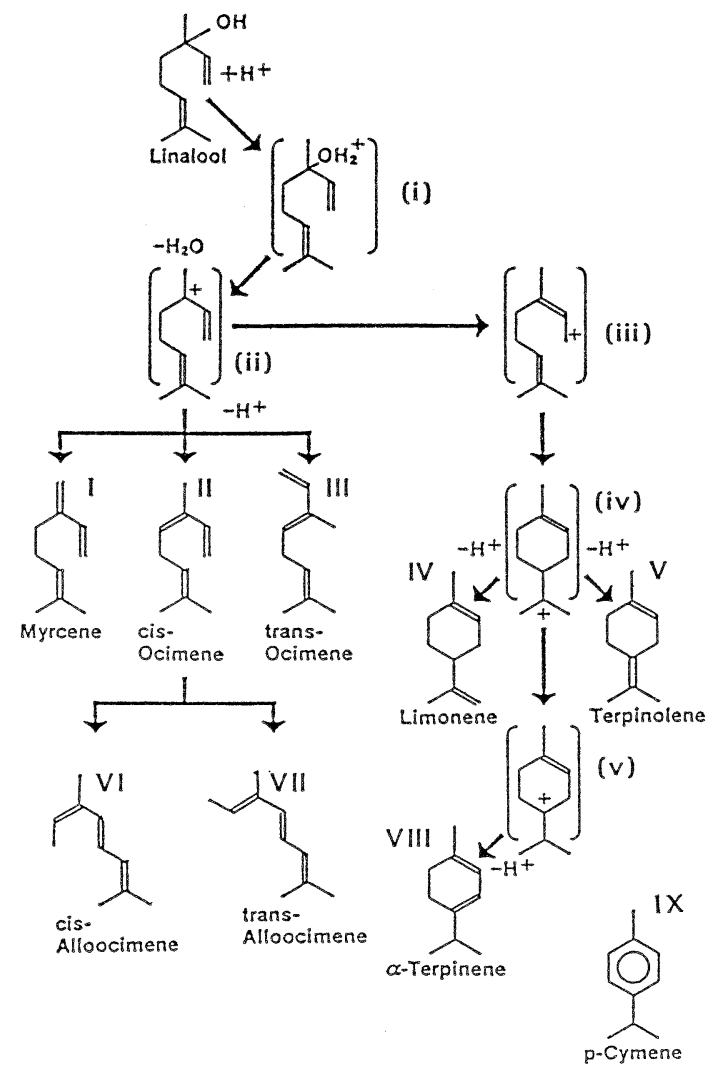

図－2 各種顔料によるリナロールの分解機機

な包いで，p-シメンについては劣化した化粧品に 特有の不快臭であることから，リナロールの反応 が進行するにしたがって不快臭になることが分か った。

また、リナロール以外でも化粧品に配合される リモネンなどのテルペン化合物も最終的には p-シ メンに変化することも考光あわせとバルス反応 法によるリナロールの分解測定は顔料による香料 劣化を推定するのに適している。この方法を用い れば窒素以外の雰囲気での反応や他の香料成分の 分解挙動も簡便に測定することがでさる。

\section{3. 化粧品における顔料の表面修飾}

化粧品に和ける顔料の表面修飾の目的は,

(1) その顔料の問題点を改良する

(2) その顔料に新しい機能を付与する の 2 点にある。
(1)については分散性の向上，光や熱括よび溶剂 などに対する耐候性の向上以外に先に述べた他成 分に対する触媒活性の抑制などがある。(2)につい ては疎水化执よび柾水疎油化処理や化粧品に揖い て必要な機能の付与があげられる。

表面修飾によっていままでと違った形態の製品 が開発されることも市り, 顔料の表面修飾は化粧 品にとって重要な技術となっている。

\section{1 金属酸化物処理}

顔料の触媒活性を封鎖するため, シリカーアル ミナで顔料を被覆する方法が提案されている ${ }^{91}$ 。 このように触媒活性を封鎖する以外に，群青の耐 酸性, 耐熱性を改善するために金属酸化物被覆が 検討された。

群青はとの構造に硫黄を持っているため, 熱や 機械的粉砕あるいは酸性条件下で容易に硫化水素 を発生し退色する。化粧品では発生する硫化水素 による変臭や銀容器の変色といった問題を引き起 こしていたが，シリカ一亜鉛華和よび亜鉛華処理 によって著しい改善効果が認められた ${ }^{10), 11) 。 ぬ ~}$ た，金属アルコキシドや金属アセチルアセトネー トを用いて気相法で微粒子を生成させた後, 再び 気相法で表面被覆したもの 化チタンと酸化ジルコニウムを披覆し, 紫外線拉 よび赤外線を防御する化粧品 ${ }^{13)}$ も提案されてい る。

\section{2 油脂 / 金属石鹸 /脂肪酸処理}

これは油脂，金属石齢和よび脂肪酸を顔料表面 に単に吸着させたり，あるいは顔料表面の水酸基 などの官能基を利用し，エステル化，エーテル化 などの化学反応を起こし, 顔料を親油性にする方 法である。球状シリカの例をとれば, 高級脂肪酸 エステル，高級アルコールなどを用いてェステル 化したり、アルキルシリル化剂を用いたアルキル エーテル化などがある ${ }^{14)}$ 。同様に, ビニル重合 体，七ルロース誘導体などの親水性高分子，ポリ エチレン，ポリアミドなどの親油性高分子で処理 する方法もある ${ }^{15)}$ 。屯た，アクリル系高分子に染 料を加えて同時に処理し，着色させる万法なども 報告されている16)。

微粒子二酸化チタンは紫外線防御能があること 
から多くの化粧品に配合されているが，表面は親 水性であるので油性製品への配合が困難な場合が 多い。そこで油脂を用いて親油化し，サンスクリ ーンなどの油性製品への配合を可能とするととも に，製品の耐水性を高める試みがなされている。 例えば炭化水素系溶媒中で脂肪酸エステルやを二 酸化チタン表面で加水分解させ，このとき，高級 アルコール残基は二酸化チタン表面の水酸基とエ ステル反応を行い, 残りの脂肪酸残基は表面の金 属イオンと金属石齢を作り，その両方によって親

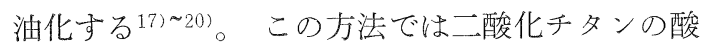
点を利用するため比較的低温で行うことができ る。

それ以外にェマルションを利用する方法があ る。炭化水素, 高級脂肪酸, 高級アルコール, エ ステル油などと界面活性剤を用いてェマルション を作り, 粉末を分散させた後, エタノールなどを 加えてェマルションを破壊することにより粉末表 面を親油化するものであり, 肌への付着性や伸び を向上することができる211。

金属石鹼は化粧品に配合された場合, 粉末の皮 膚への付着性と伸びを向上させ，また耐水性によ って化粧くずれを防ぐ効果があるため, 古くから 用いられてきだ。しかし，金属石襝を単独で多く 配合した場合, 使用感触が悪くなり, 嗳蔽性も低 くなるといった欠点があった。そこで粉末を金属 石鹼で処理する方法が開発されたが，このような 処理粉末は単純に金属石鹼を配合した場合と較べ て使用感触に優れ皮膚へのなじみも良い。

粉末としては微細球状シリカ22), 二酸化チタ ン23),24) の例があり，軽い滑らかな使用性を有し 化粧持らの良い化粧品が開発されている。

処理方法は粉末を脂肪酸のナトリウムやカリウ 厶塩水溶液に分散させて扣き，そこにアルミニウ ム，マグネシウム，カルシウム，亚鉛などの塩を 添加し，粉末表面で不溶性の金属石簽を生じさせ る25)のが一般的である。これ以外にボールミルを 用いたメカノケミカル法も開発されて和り, 脂肪 酸と粉末をボールミル処理するだけで粉末表面の 金属と脂肪酸が反応して金属石簽が生成し, 処理 できる。
脂肪酸による処理も良く知られた方法である が，微粒子のフェライトを水相中で処理し，飽和 脂肪酸基で表面被覆したものは磁性にもかかわら ず化粧料に入れても分散性に優れ，透明感のある 化粧料となる ${ }^{26)}$ 。

また，Nーアシルアミノ酸27)やそのアミド28)を 用いて処理する方法, アルミニウム塩と脂肪酸や ロジンなどの樹脂酸で処理する方法 ${ }^{291}, \mathrm{~N}$-ラウ ロイルーL-リジンで処理する方法 ${ }^{30)}$, 塩基性アミ 八酸と脂肪酸で処理する方法31などがある。

\section{3 シリコーン／ふっ素系ポリマー処理}

シリコンで処理するとはっ水性の極めて優れた 粉末が得られることから，近年この処理粉末が多 くの製品に用いられ，これに対して数多くの特許 が提出されている。

シリコーン処理の多くはメチル水素シロキサン を用いている。このものは $\mathrm{Si}-\mathrm{H}$ 基という反応性 の高い部分を持って和り，この基が顔料の表面と 反応したりこの基同志を架橋させることによって 網目状のシリコーンポリマーを顔料表面に形成さ せることができる。

例えば，メチル水素シロキサンをタルク，カオ リンなどと混合し付着させ，加熱焼き付汗により 処理し，それらを用いてはっ性の高いタルカムパ ウダーを得ている32)。また，ジィチルポリシロキ サンまたはメチル水素シロキサンを有機溶媒に溶 解した後, タルクを分散させ，必要に応じて架橋 重合触媒としてオクチル酸亜鉛を添加して焼き 付忷する方法 ${ }^{33}$, 粉末に金属水酸化物を混合摩砕 し, 粉末表面に均一に被覆した後, メチル水素シ ロキサンをメカノケミカル反応により表面上に均 一に架橋重合させ，はっ水性粉末を得る方法など がある34)。

さらに, シリコーン油または化粧品用油分を含 むシリコーン油で湿式あるいは乾式により粉末を 処理し, 高温処理したものを水乾両用ファンデー ションに配合する特許 ${ }^{35}, 36$ ? , 微粉末マイカをシリ コーン油でューティングし，焼き付け処理するこ とによって透明感を与える特許 ${ }^{37}$ などがある。

シリコーン化合物は微粒子の凝集を抑制する効 果も認められ, チタンアルコキシドの加水分解で 
生成した微粒子酸化チタンにンリコーン化合物を 添加して凝集を抑制する方法子提案されてい る ${ }^{38)}$ 。シリコーンの種類もメチル水素とシラノ一

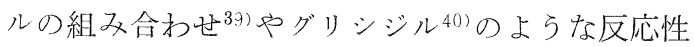
基を有するしのを用いた特許が提出されている。

シリコーン修飾に関しては複合処理の報告も多 く, 酸化チタンにシリカ扣よびアルミナを水和物 の形で被覆し, さらにンリコーン油で処理する特 許 ${ }^{41}$, 42 , さらには, こらしてシリコーン修飾され た顔料をシりコーン油や界面活性剂等と組合わせ る特許 ${ }^{43)}$,44) 毛提出されている。

フッ素化合物で処理したものは耐水性以外に耐 油性が期待できるためパーフルオロアルキル基を 有する高分子やそのリン酸およびリン酸エステ ル45) 47), 本た, シランやシロキサンによる表面処

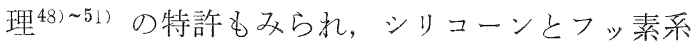
のドッキングも検討されている。

\section{4 生体関連物質による処理}

化粧品は肌飞叙布するといらことから，生体関 連物質による処理も試みられている。

例えば，水添レシチンで処理した顔料を用いた 場合，使用性は滑らかであるが，肌に対する密着 性が良く, しか子保湿性があるとの特許がある ${ }^{62)}$ また，絹フィブロインで処理した例 ${ }^{53)}$ や香料を吸 着させた多孔性フィブロイン ${ }^{54)}$ の配合, 金コロイ ドで蛋白質を染色した赤色蛋白質を配合した化粧

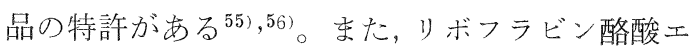
ステルのよらなビタミン誘導体を樹脂と共に被 覆 ${ }^{57)}$ したり，収歛作用のあるタンニンを蛋白質と 共に被覆58)する特許が提出されている。

\section{4. 顔料表面でのモノマーの重合と超薄膜コー ティング}

\section{1 顔料の触媒活性によるモノマーの重合}

顔料に触媒活性があるのならばその活性を利用 すれば表面でモノマーを重合させることが可能で あろら。もし，ポリマーが表面に均一に生成すれ ば，生成したポリマーによって触媒活性点が封鎖 され，從って膜は結果的に超薄膜になると考兄ら れる。この時, モノマーの供給をガス状熊で行え ば，均一性を高めることができるであるう。この
考光に従って，筆者らは種々のモノマーに上る顔 料の気相処理を検討した。この方法は一種のChemical Vapor Deposition (CVD) である。プロ ピレンオキシドは表面の固体酸によって重合する が，オリゴマーの生成にとどまり，表面を被覆す るのに充分ではなかっだ

図ー3にカオリンと紺青によって生成したポリ スチレンの GPC 結果を示す。

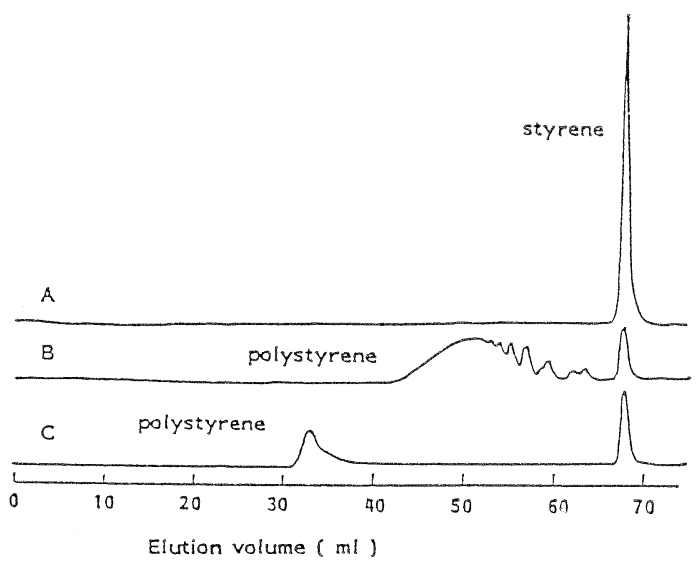

図ー3 齐種顔料によるスチレンの重合 $\mathrm{A}$ : 群青, B : カオリン, C : 絊青

カオリンでは分子量約 2,000のポリスチレンが 生成したのに対して紺青では約 300,000であり, 固体酸による重合とラジカル種による重合で分子 量が異なった60)。

また、ジメチルタイプの環状シリューンに执い ても, 顔料によってはその活性でシロキサン結合 が開裂し、シリコーンポリマーが生成した61)。し かし，直鎖状の重合では表面にポリマーが蓄積さ れるのみで超薄膜で表面を均一に被膜することは できなかった。

\section{2 反応型超薄膜コーティング}

顔料表面を超薄膜で被覆するには表面に網目状 のポリマーを形成する必要がある。1,3,5,7-テト ラメチルシクロテトラシロキサン $\left(\mathrm{H}_{4}\right)$ は 4 個の $\mathrm{Si}-\mathrm{H}$ 基を有する環状シリコーンであり, $\mathrm{Si}-\mathrm{H}$ 同 志の架橋反応によって網目状のポリマーが形成さ れる。そして反応後の $\mathrm{Si}-\mathrm{H}$ 基に付加反応によっ て機能性基が導入できることから反応型超薄膜コ 
ーティングと呼ばれている。

図一４にとの概念図を示すが，この方法は，

(1) 粉末表面でその触媒活性点を利用してシリ コーンモノマーを気相架橋重合させる62

(2) 超薄膜表面に付加反応によって機能性分子 を導入する

といった二つの工程で様々な機能性粉末を製造す る。膜の厚さはナ,メーター以下であるが, 網目 構造であるため触媒活性点は封鎖される。

このよらに超薄膜コーティングを行らと, 顔料 の触媒活性がなくなり，これを配合した化粧品の 匂安全性が高くなるが，この技術の特長は，さら にこの超薄膜に存在する $\mathrm{Si}-\mathrm{H}$ 基に不飽和化合物 の付加を行ならことができることである。

例光ばオレフィンを付加すると顔料表面にアル キル基を導入できるが，このような顔料を口紅に 配合するとオイル/ワックス系での分散が良くな るために彩度の高い鮮やかな色調を有する艶の市
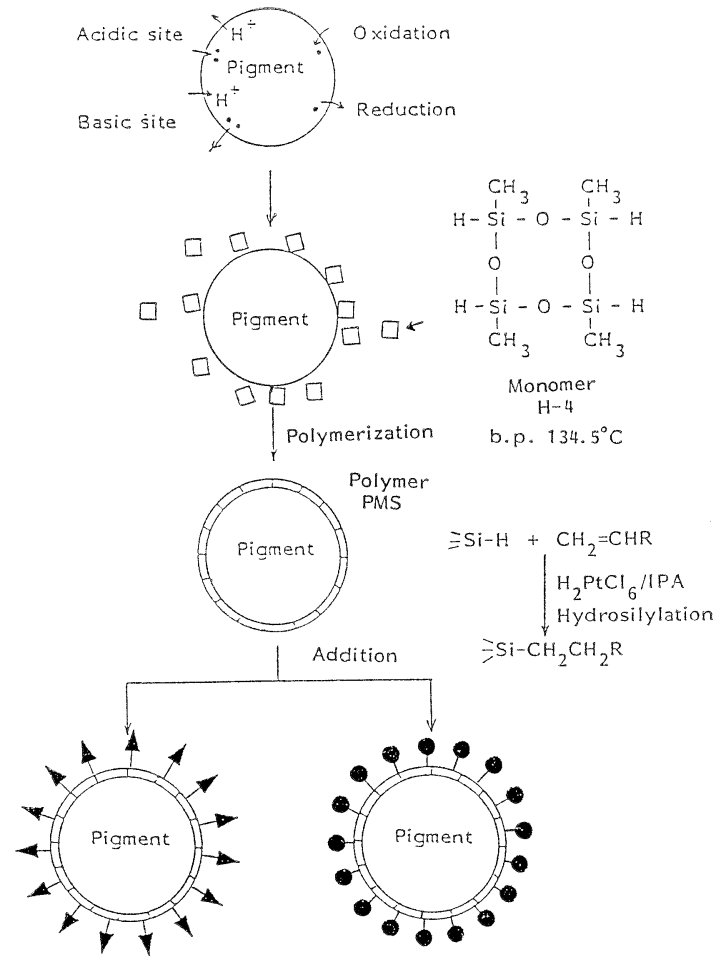

図 -4 反応型超薄膜コーティングの概念困
る口紅が得られる ${ }^{63)}$ 。また，乳化系に顔料を分散 させる場合にも希望する相に分散させることがで きる。

また，顔料の分散性以外の用途も期待できる。 例えばこの方法を用いれば薬剤や生体成分などを 粉末に固定化でき，経皮吸収性が少なく安全性に 優れた機能性材料が提供できる64) 66)。

\section{参 考 文 献}

1) K.C. Cross, J. Am. Oil Chemists' Soc, 47, 229 (1970)

2）福井 寛, 斎藤 力, 田中宗男; 色材，56，349 (1983)

3) C.D. Evans et. al., J. Am. Oil Chemists' Soc. 28, 68 (1951)

4) G. Holzner, Cosm. \& Perf., 89, 37 (1974)

5) R.J. Kokes, H. Tobin Jr., P.H. Emett, J. Am. Chem. Soc., 77, 5860 (1955)

6）村上雄一, 日化, 1977, 1587

7) T. Hattori, Y. Murakami, J. Catal., 10, 114 (1968)

8) H. Fukui, R. Namba, M. Tanaka, M. Nakano and S. Fukushima, J. Soc. Cosmetic Chemists, 38, 385 (1987)

9）脇 幹夫, 鶴田栄一, フレグランスジャーナル, 70,63 (1985)

10) 特公昭 60-9723

11）特開昭 61-236862

12) 特開平 2-307806

13) 特開平 3-76763

14）特開昭 56-81512

15）特開昭 56-68604

16) 特開平 1-294611

17）特開昭 53-124627

18）特公昭 55-24471

19）特開昭 58-43912

20）特公昭 58-42167

21）特開昭 53-127840

22）特開昭 54-140736

23）特開昭 58-49307

24）特開昭 58-62106

25）特開昭 60-69011

26) 特開平 2-292209

27）特開昭 58-72512

28) 特開平 1-172312

29）特開昭 56-79615

30) K. Esumi, S. Yoshida and K. Meguro, Bull. 
Chem. Soc. Japan, 56, 2569 (1983)

31）特開昭 61-4770

32）特公昭 45-2915

33）特公昭 45-18999

34）特開昭 56-43264

35）特開昭 56-16404

36) 特開平 3-9964

37）特開昭 56-29512

38）特開平 3-184905

39）特開昭 60-197231

40) 特開平 4-68041

41) 特開平 3-115211

42) 特開平 2-247109

43）特開昭 62-246507

44) 特開平 2-28106

45) U.S. Patent 3632744

46）特開昭 62-250074

47）特開昭 55-167209

48）特開平 1-160907

49) 特開平 4-91008

50) 特開平 2-218603

51) 特開平 3-188012

52) U.S. Patent 4622074

53）特開昭 56-128707
54）特開平 4-89421

55）特開平 3-90012

56）特開平 3-77806

57) 特開平 4-54110

58) 特開昭 63-313707

59）福井 寛, 田中宗男, 中野幹清, 色材, 58, 640 (1985)

60）福井 筧, 田中宗男, 中野幹清, 色材, 61, 277 (1988)

61）福井 寛, 難波隆二郎, 須原常夫, 山口道広, 色 材，63，589 (1990)

62) H. Fukui, T. Ogawa, M. Nakano, M. Yamaguchi and Y. Kanda, "Controlled Interphases in Composite Materials" H. Ishida, Ed., Elsevier Sci., New York (1990) p. 469

63) A. Nasu, T. Ikeda, H. Fukui and M. Yamaguchi, "International Federation Society of Cosmetic Chemists 1992"' preprint, p.691, Yokohama, 1992.

64) 特開昭 63-168346

65) 特開昭 63-171678

66) 特開平 2-191211

(1992年 2 月 3 日受理) 